\section{Hubungan promosi susu formula, produksi ASI dan psikologis ibu dengan pemberian ASI Eksklusif}

SAGO: Gizi dan Kesehatan 2020, Vol. 1(2) 159-164 (c) The Author(s) 2020

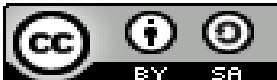

DOI: http://dx.doi.org/10.30867/sago.v1i2.409 https://ejournal.poltekkesaceh.ac.id/index.php/ Poltekkes Kemenkes Aceh

\author{
Agustina $^{1}$, Irma Hamisah², Yulia Mutia ${ }^{3}$
}

\begin{abstract}
Background: Giving breastmilk exclusively is very important for the health and development of infants. In Indonesia the scope of exclusive breastfeeding until the age of 6 months is still relatively low. This situation will have an impac on the quality of the nation's next generation and also the national economy.

Objectives: To obtain the relationship between the promotion of formula milk, Breastmilk production and psychological factor of mother with exclusive breastfeeding in the work area of the Bireuen Peusangan health center.

Methods: This research is analytic descriptive with cross sectional approach. This research was conducted in the Peusangan Bireuen Community Health Center from 19 February-4 March 2018. The number of samples was 67 mothers who had babies aged 7-11 months. Data processing was carried out with SPSS and Chi-Square statistical test analysis with p-value $<0.05$.

Results: The results showed that 43 people (64.2\%) gave exclusive breastfeeding, ther was relationship between exclusive breastfeeding and the promotion of formula milk $(p=0.032)$, Breastmilk production $(p=0.047)$, but not related to psychology $(p=0,830)$.

Conclusion: Breastmilk production and promotion of formula milk are related to exclusive breastfeeding.
\end{abstract}

\title{
Keywords
}

Exclusive breastfeeding, formula milk, breast milk production, mother psychological.

\begin{abstract}
Abstrak
Latar Belakang: Pemberian Air Susu Ibu (ASI) secara eksklusif sangat lah penting bagi kesehatan dan perkembangan bayi. Di Indonesia cakupan pemberian ASI eksklusif sampai umur bayi 6 bulan masih tergolong rendah. Keadaan ini akan berdampak pada kualitas generasi penerus bangsa dan juga perekonomian nasional.

Tujuan: untuk mengetahui hubungan promosi susu formula, produksi ASI dan psikologis ibu dengan pemberian ASI eksklusif di wilayah kerja puskesmas peusangan Bireuen.

Metode: Penelitian ini bersifat deskriptif analitik dengan pendekatan cross sectional. Penelitian ini dilaksanakan di Wilayah Kerja Puskesmas Peusangan Bireuen dari tanggal 19 Februari - 4 Maret 2018. Jumlah sampel 67 ibu yang memiliki bayi usia 7-11 bulan. Pengolahan data dilakukan dengan SPSS dengan analisa uji statistic Chi-Square dengan $\mathrm{p}$ value $<0,05$.

Hasil: Hasil penelitian menunjukkan responden yang memberikan ASI eksklusif sebanyak 43 orang (64.2\%), terdapat hubungan antara pemberian ASI eksklusif dengan promosi susu formula $(p=0.032)$, produksi ASI $(p=0.047)$ namun tidak berhubungan dengan psikologis $(p=0.830)$.

Kesimpulan: Produksi ASI, promosi susu formula berhubungan dengan pemberian ASI eksklusif.
\end{abstract}

\footnotetext{
${ }^{1}$ Fakultas Kesehatan Masyarakat Universitas Muhammadiyah Aceh. E-mail: agustina.260880@gmail.com

2 Fakultas Kesehatan Masyarakat Universitas Muhammadiyah Aceh. E-mail: ssah783@gmail.com

${ }^{3}$ Fakultas Kesehatan Masyarakat Universitas Muhammadiyah Aceh. E-mail: yuliamutia23@gmail.com
} 


\section{Kata Kunci}

ASI Eksklusif, Susu Formula, Produksi ASI, Psikologis Ibu

\section{Pendahuluan}

Air Susu Ibu (ASI) merupakan nutrisi alamiah terbaik bagi bayi karena mengandung kebutuhan energi dan zat yang dibutuhkan selama enam bulan pertama kehidupan bayi. Seorang ibu sering mengalami masalah dalam pemberian ASI eksklusif, salah satu kendala utamanya yakni produksi ASI yang tidak lancer. Hal ini akan menjadi factor penyebab rendahnya cakupan pemberian ASI eksklusif kepada bayi baru lahir (wulandari \& Handayani, 2011).

World Health Organization (WHO) dan United Nations Childrens Fund (UNICEF) merekomendasikan agar ibu menyusui bayinya satu jam pertama setelah melahirkan dan melanjutkan hingga usia 6 bulan pertama kehidupan bayi. Pengenalan makanan pelengkap dengan nutrisi yang memadai aman diberikan saat bayi memasuki usia 6 bulan dengan terus menyusui sampai usia 2 tahun atau lebih (Eidelman \& Schanler, 2012).

UNICEF memperkirakan bahwa pemberian Asi Eksklusif sampai usia 6 (enam) bulan dapat mencegah kematian 1.3 juta anak berusia di bawah lima tahun. Suatu penelitian di Ghana yang diterbitkan dalam jurnal Pediatrics menunjukkan $16 \%$ kematian bayi dapat dicegah melalui pemberian Asi pada bayi sejak hari pertama kelahirannya. Angka ini naik mejadi 22\% jika pemberian Asi dimulai dalam satu jam pertama setelah kelahiran bayi (Rahmawati, 2010).

Tujuan dari pembangunan Kesehatan di Indonesia tahun 2010-2014, maka tahun 2015 Kementerian Kesehatan Indonesia menetapkan tujuan pembangunan Kesehatan di Indonesia yaitu salah satunya menurunkan angka kematian bayi dari 32 menjadi 24 per 1,000 kelahiran hidup. Sehubungan dengan Sustainable Development Goals (SDGs) atau Tujuan Pembangunan berkelanjutan 2030, menyusui merupakan salah satu Langkah pertama bagi seorang manusia untuk mendapatkan kehidupan yang sehat dan sejahtera. Sayangnya, tidak semua orang mengetahui hal ini. Di beberapa negara maju dan berkembang termasuk Indonesia, banyak ibu karir yang tidak menyusui secara eksklusif. Di Indonesia hamper 9 dari 10 ibu pernah memberikan ASI, namun penelitian IDAI menemukan hanya $49.8 \%$ yang memberikan ASI secara eksklusif ini dapat berdampak pada kualitas hidup generasi penerus bangsa dan juga pada perekonomian nasional (WHO, 2016).

Di Indonesia cakupan ASI eksklusif tahun 2014 sebesar 52.3\%. Sedangkan pada tahun 2015 cakupan ASI eksklusif meningkat menjadi 55.7\% dan pada tahun 2016 capaian ASI eksklusif Indonesia Kembali menurun sebesar 46\% (Kemkes, 2017).

Berdasarkan data yang diperoleh dari Dinas Kesehatan provinsi Aceh pada tahun 2014 di Aceh cakupan ASI eksklusif sebanyak 55.4\%, sedangkan tahun 2015 cakupan ASI eksklusif meningkat mencapai 58.3\% dan pada tahun 2016 cakupan ASI eksklusif di Aceh kembali menurun sebanyak 41\% (Kemenkes, 2017). Hal ini disebabkan oleh beberapa faktor antara lain budaya memberikan makanan, memberikan tambahan susu formula karena ASI tidak keluar, menghentikan pemberian ASI eksklusif karena bayi atau ibu sakit, ibu harus bekerja, dan ibu ingin mencoba susu formula (ALRahmad et al., 2013).

Berdasarkan profil Dinas Kesehatan Bireuen tahun 2017, pada tahun 2014 di Bireuen jumlah bayi yang mendapatkan ASI eksklusif sebesar 57.9\%, sedangkan pada tahun 2015 jumlah bayi yang mendapatkan ASI ekslusif menjadi 55.6\% dan pada tahun 2016 jumlah bayi yang mendapatkan ASI eksklusif semakin menurun drastis hanya $35.4 \%$ (Dinkes Bireuen, 2017).

Berdasarkan data yang diperoleh dari puskesmas Peusangan Kabupaten Bireuen. pada tahun 2014 jumlah bayi yang mendapatkan ASI eksklusif sebanyak $57.6 \%$, sedangkan pada tahun 2015 jumlah bayi yang mendapatkan ASI eksklusif menurun sebesar $17.3 \%$. Jumlah bayi umur 0-6 bulan dari 38 desa pada bulan oktober tahun 2017 yang mendapatkan ASI eksklusif sebanyak 113 orang $(57.51 \%)$ dan yang tidak mendapatkan ASI eksklusif sebanyak 153 orang (42.48\%). jumlah bayi 0-6 bulan. Sedangkan pada bulan November 2017 yang mandapatkan ASI eksklusif meningkat menjadi 147 orang $(63.63 \%)$ dan yang tidak mendapatkan ASI eksklusif sebanyak 84 orang (36.36\%), yang disebabkan oleh factor ibu bekerja, ibu yang sudah memberikan susu formula sehingga ASI eksklusif tidak terpenuhi kepada bayinya dan disebabkan 
juga karena kebiasaan ibu yang memberikan pisang kepada bayinya sehingga mengalami diare, sembelit, muntah dan alergi (puskesmas peusangan, 2017).

Tujuan dari penelitian ini adalah untuk mengetahui bagaiaman hubungan pemberian susu formula, produksi ASI dan psikologi ibu dalam memberikan ASI dengan pemberian ASI eksklusif oleh ibu menyusui di wilayah kerja Puskesmas Peusangan Kabupaten Bireuen.

\section{Metode}

Jenis penelitian ini bersifar deskriptif analitik yaitu penelitian penjelasan yang berkaitan dengan hubungan-hubungan variabel-variabel penelitian seta menguji hipotesis yang telah dirumuskan sebelumnya dengan pendekatan crossectional yaitu pendekatan penelitian yang mengambil sampel dalam waktu yang bersamaan.

Populasi dalam penelitian ini yaitu seluruh ibu yang memiliki bayi usia 7-11 bulan di wilayah kerja Puskesmas Peusangan pada bulan Desember tahun 2017 yang berjumlah 203 orang. jumlah sampel yaitu 67 orang responden. Metode pengambilan sampel dengan menggunakan simple

Tabel 1. Hubungan produksi ASI, promosi susu formula dan pasikologis ibu dengan pemberian ASI eksklusif

\begin{tabular}{|c|c|c|c|c|c|c|c|}
\hline \multirow{3}{*}{ Variabel Independen } & \multicolumn{4}{|c|}{ Pemberian ASI Eksklusif } & \multirow{2}{*}{\multicolumn{2}{|c|}{ Total }} & \multirow{3}{*}{ Nilai $\mathrm{p}$} \\
\hline & \multicolumn{2}{|c|}{ Tidak } & \multicolumn{2}{|c|}{ Eksklusif } & & & \\
\hline & $f$ & $\%$ & $f$ & $\%$ & $f$ & $\%$ & \\
\hline \multicolumn{8}{|l|}{ Produksi ASI } \\
\hline Tidak lancar & 15 & 22.4 & 16 & 23.9 & 31 & 46.3 & 0.047 \\
\hline Lancar & 9 & 13.4 & 27 & 40.3 & 36 & 53.7 & \\
\hline \multicolumn{8}{|l|}{ Promosi Susu Formula } \\
\hline Tidak Pernah & 20 & 29.9 & 24 & 35.8 & 44 & 65.7 & 0.023 \\
\hline Pernah & 4 & 6.0 & 19 & 28.4 & 23 & 34.3 & \\
\hline \multicolumn{8}{|l|}{ Psikologis Ibu } \\
\hline Cemas & 15 & 22.4 & 28 & 41.8 & 43 & 64.2 & 0.830 \\
\hline Tidak Cemas & 9 & 13.4 & 15 & 22.4 & 24 & 35.8 & \\
\hline Total & 24 & 35.8 & 43 & 64.2 & 67 & 100.0 & \\
\hline
\end{tabular}

Berdasarkan tabel diatas menunjukkan bahwa persentase yang tidak memberikan ASI eksklusif lebih besar pada responden yang tidak pernah mendapatkan promosi susu formula (29.9\%) dibandingkan responden yang pernah mendapatkan promosi susu formula (6.0\%). Sebaliknya persentase yang memberikan ASI eksklusif lebih rendah pada responden yang pernah mendapatkan promosi susu formula random sampling. Instrumen yang digunakan berupa kuesioner. Analisis uji statistik menggunakan metode chi square dan disajikan dalam bentuk tabel dan narasi.

\section{Hasil}

Berdasarkan penelitian yang telah dilakukan terhadap 67 responden pada 36 desa di wilayah kerja puskesmas Peusangan Kabupaten Bireuen tentang pemberian ASI eksklusif pada ibu menyusui diperoleh hasil penyajian dalam bentuk table.

Berdasarkan table diatas menunjukkan persentase yang tidak memberikan ASI eksklusif lebih besar pada responden yang produksi ASI lancer (22.4\% dibandingkan dengan responden yang produksi ASI lancer (13.4\%). Sebaliknya persentase yang memberikan ASI eksklusif lebih besar pada responden dengan produksi ASI lancer (40.3\%) dibandingkan dengan responden yang produksi ASI tidak lancer (23.9\%). Hasil uji statistik menunjukkan bahwa ada hubungan yang bermakna antara produksi ASI dengan pemberian ASI Eksklusif dengan $p$ value $=0.047(p<0.05)$. 
dibandingkan dengan responden yang psikologis tidak cemas (13.4\%). Sebaliknya persentase yang memberikan ASI eksklusif lebih rendah pada responden yang psikologis tidak cemas (35.8\%) dibandingkan dengan responden yang psikologis cemas (22.4\%). Hasil uji statistic menunjukkan bahwa tidak terdapat hubungan yang bermakna antara psikologis dengan pemberian ASI eksklusif dengan $p$-value $=0.830(p>0.05)$.

\section{Pembahasan}

\section{Hubungan Produksi ASI dengan Pemberian ASI Eksklusif}

Pemberian ASI eksklusif sangat berkaitan erat dengan keberhasilan memberikan ASI secara maksimal kepada bayi. Dengan produksi ASI yang cukup maka kebutuhan bayi akan terpenuhi. Tanda bahwa produksi ASI cukup yaitu sebelum disusui payudara ibu terasa tegang, ASI dapat keluar dari putting dengan sendirinya setelah menyusu maka bayi akan tertidur atau tenang selama 1-2 jam.

Salah satu parameter utama yang digunakan untuk menilai apakah bayi cukup Asi adalah dengan mengamati pertumbuhan bayi yaitu melalui penambahan berat badan. Oleh karena itu setiap bulan ibu sebaiknya mengukur pertumbuhan fisik bayi termasuk menimbang berat badan dan mengukur tinggi badan. Ibu dapat bertanya kepada petugas kesehatan tentang pertumbuhan bayi dan memahami kurva pertumbuhan dalam Kartu Menuju Sehat (KMS) (Marmi, 2012).

Rekomendasi dari WHO bahwa pemberian Asi Eksklusif dimulai dari 6 (enam) bulan pertama kelahiran dan dilanjutkan dengan pengenalan Makanan Pendamping Asi (MP-ASI) dengan terus melanjutkan pemberian Asi sampai usia 2 (dua) tahun. Selama 500 hari pertama, dari konsepsi hingga sekitar 6 (enam) bulan, anak sepenuhnya tergantung pada asupan nutrisi ibu, baik selama masa kehamilan maupun selama 6 (enam) bulan masa pemberian Asi Eksklusif. Waktu transisi dari 500 dari pemberian Asi Eksklusif selama 6 (enam) bulan dan mengkonsumsi berbagai makanan pendamping, sedangkan proses menyusui terus berlanjut. Pemberian makanan pendamping yang adekuat sangat penting untuk mendukung pertumbuhan fisik yang optimal dan perkembangan otak anak.
Dampak yang terjadi jika ibu tidak menyusui bayinya yaitu terputusnya hubungan batin antara sang ibu dengan anak, rasa sakit pada payudara yang membengkak saat diperah atau saat digunakan pompa atau mesin pompa ASI, ketidakseimbangan antara produksi ASI/hari (Manggabarni, Hadi \& Bunga, 2018).

Sesuai penelitian Diah, 2011, menunjukkan ada hubungan kelancaran produksi ASI dengna pemberiaan ASI eksklusif. Menurut Suriviana (2005), persiapan ibu menyusui mulai dari enam minggu sebelum melahirkan, mulai memijat-mijat payudaranya untuk merangsang mengalirnya aliran darah ke payudara. Menyusui bayi sedini mungkin juga dapat meningkatkan kelancaran produksi ASI.

\section{Hubungan Promosi Susu Formula dengan Pemberian ASI Eksklusif}

Kelancaran pemberian ASI eksklusif salah satunya adalah atas adanya keinginan ibu menyusui sendiri. Hal tersebut sejalan dengan penelitian sebelumnya bahwa pengambilan keputusan terkait asupan nutrisi yang diberikan pada bayi ada pada ibu sendiri, pengaruh ibu sangat besar dalam mengambil keputusan untuk memberikan ASI eksklusif (kemenkes. 2013.).

Penelitian ini ada hubungannya dengan promosi susu formula. Namun kenyataannya dalam penelitian ini masih ada tempat tempat persalinan yang menjadi sarana untuk produsen susu formula, bahkan ada tenaga Kesehatan yang bekerja sama untuk menjual susu formula.

Semua ibu pernah terpapar iklan susu formula, baik melalui media elektronik maupun cetak, tetapi tidak semua ibu pernah melihat ilkan mengenai ASI. Kondisi ini dapat mengakibatkan ibu menganggap susu formula sama dengan ASI atau bahkan lebih baik dari ASI (Alamsyah 2017).

Pada bayi yang diberikan Asi Eksklusif pertambahan tinggi badan akan seimbang sesuai dengan usia, sedangkan berat badan bayi yang mendapatkan Asi pada umumnya lebih ringan daripada bayi yang mendapatkan makanan tambahan. Hal ini karena Asi mengandung leptin yang merupakan hormon pengatur nafsu makan dan metabolisme energi. Berat badan lebih pada bayi yang mendapatkan makanan tambahan justru menandakan terjadinya kegemukan atau obesitas, keadaan ini tidak baik untuk kesehatan (Khasanah, 2011). 
Menurut Afifah, 2007, salah satu faktor penghambat pemberian ASI eksklusif adalah keterpaparan promosi susu formula. Pemberian susu formula sering dilakukan di BPS, RB maupun RS dengan alas an utama karena ASI belum keluar dan bayi masih kesulitan menyusu sehingga bayi akan menangis bila dibiarkan saja. Biasanya bidan akan langsung memberikan nasihat untuk memberikan susu formula. Hal ini juga akan memberi pengaruh negative terhadap keyakinan ibu bahwa memberi susu formula adalah hal yang paling ampuh untuk menghentikan tangis bayi.

Bayi yang diberi Asi Eksklusif akan mencapai status gizi yang baik, tetapi ada juga bayi yang diberi susu formula mengalami kurang gizi. Hal ini karena pembuatan susu dengan air yang melebihi ketentuan yang bukan saja menurunkan kadar kalori, tetapi juga protein sehingga kebutuhan bayi akan kedua zat gizi utama tidak terpenuhi (Khasanah, 2011).

Penelitian juga mendapatkan anak-anak yang tidak mendapatkan Asi mempunyai IQ lebih rendah 7-8 poin dibandingkan dengan anak-anak yang mendapatka Asi secara Eksklusif dan peluang kematian 25 kali lebih tinggi pada bayi yang diberikan susu formula (Suririnah, 2010).

Manary dan Solomon (2004) dalam Khasanah (2011) menyatakan bahwa frekuensi atau durasi pemberian Asi yang tidak cukup menjadi faktor untuk terjadinya defisiensi makronutrien maupun micronutrient pada usia dini. Keadaan gizi kurang yang banyak ditemukan pada bayi-bayi terlihat ketika para ibu di daerah perkotaan memilih untuk menggunakan susu formula sebagai pengganti Asi.

\section{Hubungan Psikologis dengan Pemberian ASI Eksklusif}

Hasil penelitian ini tidak menunjukkan hubungan antara psikologis dengan pemberian ASI eksklusif. Factor psikologis seperti kekhawatiran dan ketidakstabilan adalah paling efektif untuk mengurangi atau menghilangkan sekresi susu. Seorang ibu yang mau menyusui yakin bahwa dirinya bisa. Stress dan cemas serta ketidakyakinan sangat mempengaruhi produksi hormon yang berperan dalam proses menyusui atau mungkin ibu kecewa pada setiap kesan bahwa jumlah dan kualitas susunya dapat berkurang. Seperti halnya hasil kualitatif yang menyatakan bahwa hampir semua partisipan merasa bahwa ASI saja itu tidak cukup bagi bayinya. Hal ini menyebabkan mereka memberikan MP-ASI dan PASI sebelum waktunya.

Adanya anggapan para ibu bahwa menyusui akan merusak penampilan sehingga ibu takut kehilangan daya tarik sebagai seorang wanita. Sebagian kecil ibu mengalami tekanan batin di saat menyusui bayi sehingga dapat mendesak ibu untuk mengurangi frekuensi dan lama menyusui bayinya bahkan tidak memberikan ASI. Padahal dengan menyusui akan membantu menumbuhkan ikatan psikologi antara ibu dan bayinya, menghadirkan rasa aman dan tenang, merangsang produksi Asi, serta memperlancar ASI (Al-Rahmad \& Fadillah, 2017). Bila kondisi ini terus dipertahankan hingga kondisi bayi berumur 2 9dua) tahu maka ia akan jarang menangis atau rewel, pertumbuhan dan perkembangannyapun akan cepat (Soetjiningsih, 2012).

Berdasarkan hasil penelitian tentang faktorfaktor yang mempengaruhi perilaku pemberian ASI eksklusif pada ibu, menunjukkan adanya anggapan para ibu bahwa menyusui akan merusak penampilan. Hampir semua partisipan merasa bahwa ASI saja tidak cukup bagi bayinya sehingga mereka memberikan makanan tambahan pada bayinya (Josefa, 2010)

\section{Kesimpulan}

Terdapat hubungan Produksi ASI, promosi susu formula dengan pemberian ASI eksklusif dan tidak ada hubungan psikologis ibu dengan pemberian ASI eksklusif di wilayah kerja Puskesmas Peusangan Bireuen

\section{Deklarasi Konflik Kepentingan}

Penulis telah menyatakan bahwa pada artikel ini tidak ada maupun terdapat potensi konflik kepentingan baik dari penulis maupun instansi sehubungan dengan penelitian yang telah dilakukan, baik berdasarkan kepengarangan, maupun publikasi.

\section{Ucapan Terima Kasih}

Ucapan terimakasih disampaikan kepada Dekan Fakultas Kesehatan Masyarakat Universitas Muhammadiyah Aceh, Dinas Kesehatan Bireuen dan Puskesmas Peusanngan yang telah membantu 
kontribusi terhadap pelaksanaan penelitian. Selain itu, ucapan terima kasih juga kami sampaikan kepada tim pakar yang telah membantu perbaikan baik secara teknis maupun isi dalam pelaksanaan penelitian ini.

\section{Daftar Rujukan}

Afifah. (2007). Faktor Yang Berperan Dalam Kegagalan Pemberian ASI Eksklusif, 2007 http://magl.undip.ac.id/penelitian/versiindonesia. ( 06 Desember 2017)

AL-Rahmad, A. H., Miko, A., \& Hadi, A. (2013). Kajian stunting pada anak balita ditinjau dari pemberian ASI eksklusif, MP-ASI, status imunisasi dan karakteristik keluarga di Kota Banda Aceh. J Kesehatan Ilmiah Nasuwakes, 6(2), 169-184.

Alamsyah D, Marlenywati, Ruthayana H. Hubungan antara kondisi kesehatan ibu, pelaksanaan IMD, dan iklan susu formula dengan pemberian ASI eksklusif. Jurnal IKESMA 2017.

Al-Rahmad, A. H., \& Fadillah, I. (2017). Perkembangan Psikomotorik Bayi 6-9 Bulan berdasarkan Pemberian ASI Eksklusif. Aceh Nutrition Journal, 1(2), 99-104.

Diah, A.L, (2011), Faktor yang mempengaruhi keberhasilan dalam pemberian ASI eksklusif di BPS PIPIN Heriyanti Kota Yogyakarta

Dinkes Bireuen, Profil Kesehatan Kabupaten Bireuen, Bireuen : Dinkes Kabupaten Bireuen, 2017

Josefa, KG. (2010). Faktor-faktor Yang Mempengaruhi Prilaku Pemberian ASI Eksklusif Pada lbu, 2010. http://eprints.undip.ac.id/3391/. November 2017)

Kementerian Kesehatan Republik Indonesia. (2013) Profil Kesehatan Indonesia 2013. Jakarta: Kementerian Kesehatan Republik Indonesia

Kemenkes RI. (2016). Data Dan Informasi Profil Kesehatan Indonesia 2016, Jakarta : Kemenkes RI, 2017

Khasanah, N. (2011). Asi Atau Susu Formula Ya?, Jogjakarta : Flashbook

Marmi. (2012). ASI Saja Mama...Karena Aku Bukan Anak Sapi, Yogyakarta : Pustaka Pelajar

Purnomo I.S. (2009). Bahan Bacaan Manajemen Laktasi Cetakan Ke-4, Jakarta : Perkumpulan Perinatologi Indonesia
Puskesmas Peusangan, Laporan Gizi Puskesmas Peusangan, Matangglumpangdua : Puskesmas Peusangan, 2017

Rahmawati. (2010). Perawatan Nifas, Yogyakarta : Fitramaya

Soetjiningsih, Asi Petunjuk Tenaga Kesehatan, Jakarta : EGC, 2012

Suririnah, H. (2010). Gizi Untuk Kesehatan Ibu dan Anak, Yogyakarta : Graha Ilmu

WHO, UNiCEF, Global Strategy For Infant and Young Child Feeding, 2016. http://www.who/nutrition/publication/infan tfeeding (01 November 2017)

Wulandari, setyo Retno dan Sri Handayani, Asuhan Kebidanan Ibu Masa Nifas (Cet.I), Yogyakarta : Gosyen, 2011 